4. Calafiore AM, Giammarco GD, Teodori G, Bosco G, D’Annunzio E, Barsotti A, et al. Left anterior descending coronary artery grafting via left anterior small thoracotomy without cardiopulmonary bypass. Ann Thorac Surg. 1996;61: 1658-63; discussion 1664-5.

5. Davierwala PM, Leontyev S, Garbade J, Lehmann S, Holzhey D, Misfeld M, et al. Off-pump coronary artery bypass surgery with bilateral internal thoracic arteries: the Leipzig experience. Ann Cardiothorac Surg. 2018;7:483-91.

6. Davierwala PM, Sgouropoulou S, Hasheminejad E, Von Aspern K, Misfield M, Borger MA. Minimally invasive coronary bypass surgery with bilateral internal thoracic arteries: early outcomes and angiographic patency. J Thorac Cardiovasc Surg. 2021;162:1109-19.e4
7. Lytle BW. Bilateral internal thoracic artery grafting. Ann Cardiothorac Surg. 2013;2:485-92.

8. Gaudino M, Angelini GD, Antoniades C, Bakaeen F, Benedetto U, Calafiore AM, et al; Arterial Grafting International Consortium (ATLANTIC) Alliance. Offpump coronary artery bypass grafting: 30 years of debate. J Am Heart Assoc. 2018;7:e009934.

9. Salerno TA, Ferreira AC. Is conventional coronary artery surgery being replaced by the hybrid approach? J Thorac Cardiovasc Surg. 2016;151: 1702-3

10. Calafiore AM, Angelini GD, Bergsland J, Salerno TA. Minimally invasive coronary artery bypass grafting. Ann Thorac Surg. 1996;62:1545-8.
See Article page 1109.

\section{Commentary: Coronary artery bypass with bilateral internal thoracic arteries: Could smaller be considered better?}

\section{Daniel J. P. Burns, MD, MPhil}

The sternotomy remains the most common approach for most cardiac surgical procedures, allowing for excellent exposure, predictability, and a high degree of surgical control. When adopting a minimally invasive approach, a central principle is that the results achieved must be, at minimum, the same as the conventional counterpart. If this can be achieved, then the minimally invasive approach can be considered better. However, it must also be recognized that as invasiveness decreases, complexity increases, and control over the procedure is necessarily diminished. In cardiac surgery, where there are multiple interactions necessary for the procedure, it is crucial to respect the balance between these factors. Minimally invasive cardiac surgery typically focuses on valve interventions. Although certain specialized centers have taken up minimally invasive coronary artery interventions enthusiastically, these complex and technically challenging procedures are less common than their valve counterparts.

When considering coronary artery bypass grafting (CABG), we continue to debate the merits of different

\footnotetext{
From the Department of Thoracic and Cardiovascular Surgery, Cleveland Clinic Foundation, Cleveland, Ohio.

Disclosures: Dr Burns is a consultant to Medtronic.

Received for publication Jan 4, 2020; revisions received Jan 4, 2020; accepted for publication Jan 5, 2020; available ahead of print Jan 31, 2020.

Address for reprints: Daniel J. P. Burns, MD, MPhil, Cleveland Clinic, 9500 Euclid Ave, J4-133, Cleveland, OH 44195 (E-mail: burnsd@ccf.org).

J Thorac Cardiovasc Surg 2021;162:1121-2

$0022-5223 / \$ 36.00$

Copyright (c) 2020 by The American Association for Thoracic Surgery

http://dx.doi.org/10.1016/j.jtcvs.2020.01.024
}

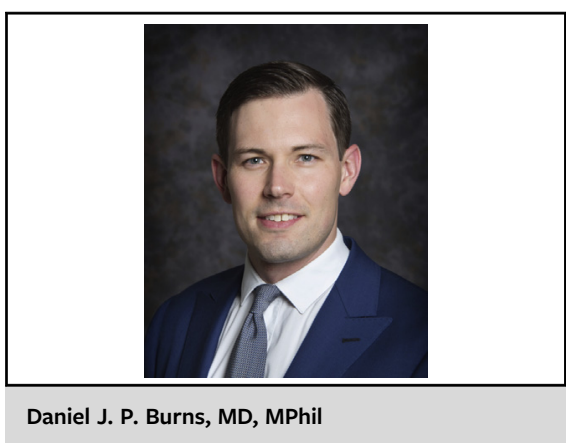

CENTRAL MESSAGE

Sternal-sparing minimally invasive coronary artery bypass using bilateral internal thoracic arteries can be performed safely with encouraging early patency results.

grafting strategies. It has been demonstrated that arterial grafts, when used correctly, can be expected to outlast saphenous vein grafts. ${ }^{1,2}$ Clinically, however, bilateral internal thoracic artery (BITA) use has shown inconsistent evidence. Although observational studies appear to support its use, a recent prominent trial demonstrated no mortality difference at 10 years. ${ }^{3,4}$ The question of BITA use in CABG should by no means be considered settled.

In this issue of the Journal, Davierwala and colleagues ${ }^{5}$ have endeavored to tackle both problems: minimally invasive multiarterial revascularization and use of bilateral internal thoracic arteries. ${ }^{5}$ Off-pump, minimally invasive, multivessel CABG via a left anterior thoracotomy was performed in 88 patients. BITA harvest was undertaken in a skeletonized fashion under direct vision. Y-grafting was used to avoid aortic manipulation. Overall results are encouraging. There was an absence of in- 
hospital mortality, although a single postoperative arrest required extracorporeal membrane oxygenation, and there was 1 perioperative myocardial infarct. A single patient had a mortality event within 30 days. Respiratory complications were more common, with 12 outcome events. Multivariable regression demonstrated increased odds of respiratory complications with an increased length of surgery (odds ratio, 1.02, 1.008-1.034). Internal thoracic artery patency was excellent postoperatively, with an overall angiographic patency of $96.8 \%$.

This study needs to be interpreted within the context of some major limitations. This is a small noncomparative series. The patient population is heavily selected, with patients having more optimal body habitus, ejection fraction, and ventricular dimensions. The right coronary system was grafted far less frequently in this series (9 patients), suggesting selection against right coronary territory grafting. Although multivariable regression was used to determine predictors of respiratory complications, a small study population with relatively few outcome events makes these results less reliable. Finally, although angiography demonstrated excellent early patency, what really matters is how these grafts fare in the long term.
This study demonstrates that minimally invasive multiarterial revascularization is safe and reproducible without requiring advanced endoscopic or robotic assistance. Although more comprehensive and longterm study is required, this represents an important incremental step in the evolution of minimally invasive CABG.

\section{References}

1. Sabik JF III, Lytle BW, Blackstone EH, Houghtaling PL, Cosgrove DM. Comparison of saphenous vein and internal thoracic artery graft patency by coronary system. Ann Thorac Surg. 2005;79:544-51

2. Deb S, Cohen EA, Singh SK, Une D, Laupacis A, Fremes SE; RAPS Investigators. Radial artery and saphenous vein patency more than 5 years after coronary artery bypass surgery: results from RAPS (radial artery patency study). J Am Coll Cardiol. 2012;60:28-35.

3. Yi G, Shine B, Rehman SM, Altman DG, Taggart DP. Effect of bilateral internal mammary artery grafts on long-term survival a meta-analysis approach. Circulation. 2014; 130:39-45.

4. Taggart DP, Benedetto U, Gerry S, Altman DG, Gray AM, Lees B, et al. Bilateral versus single internal thoracic artery grafts at 10 years. N Engl J Med. 2019;380: 437-46.

5. Davierwala PM, Verevkin A, Sgouropoulou S, Hasheminejad E, von Aspern K, Misfeld M, Borger MA. Minimally invasive coronary bypass surgery with bilateral internal thoracic arteries: early outcomes and angiographic patency. J Thorac Cardiovasc Surg. 2021;162:1109-19.e4.
See Article page 1109.

\section{Commentary: The evolution of coronary artery bypass surgery: Toward a better operation}

\author{
Michael P. Vallely, MD, PhD, ${ }^{\mathrm{a}}$ Irbaz Hameed, MD, \\ and Mario Gaudino, $\mathrm{MD}^{\mathrm{b}}$
}

"Insanity is doing the same thing over and over again and expecting different results."

-Albert Einstein
Check for updates

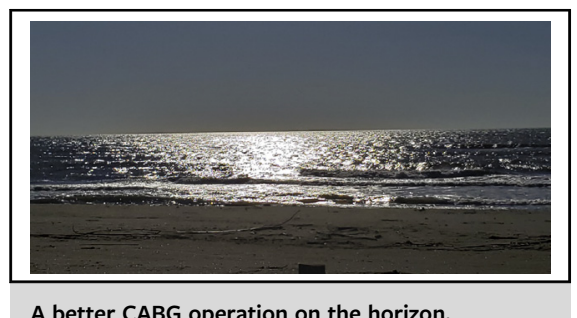

A better CABG operation on the horizon.

CENTRAL MESSAGE

Sternal-sparing surgery completely

avoids sternal wound infection.

The evidence for the potential long-term benefits of multiple arterial grafts has been available for approximately 3 decades. The survival benefit of the use of bilateral 